\title{
PENGARUH KOMPETENSI DAN MOTIVASI TERHADAP KINERJA PEGAWAI PADA PT XXX
}

\section{THE EFFECT OF COMPETENCE AND MOTIVATION ON EMPLOYEE PERFORMANCE ON PT XXX}

\author{
Erni Yuningsih'); Ardianti ${ }^{2)}$ \\ Program Studi Manajemen Fakultas Ekonomi Universitas Djuanda Bogor \\ Email: erni.yuningsih@unida.ac.id; ardianti3008@gmail.com
}

\begin{abstract}
This study aims to determine the effect of competence and motivation on employee performance at PT XXX. The questionnaire was distributed to 82 employees. The method used in this study is the survey method, the form of research is descriptive and verification. The questionnaire was tested using validity and reliability tests. Likert scale is used before analysis with multiple regression. This is to determine the effect of two independent variables used on one dependent variable. The results of this study based on the results of validity and reliability tests indicate that all indicators are declared valid and reliable. Simultaneously competency and motivation have a positive and significant effect on employee performance on $X X X$. While partially competence has a positive and significant effect on employee performance, and motivation has a positive and significant effect on employee performance at PT XXX.
\end{abstract}

Keywords: Competence, Motivation and Employee Performance

\begin{abstract}
ABSTRAK
Penelitian bermaksud untuk mengetahui pengaruh kompetensi juga motivasi pada kinerja pegawai PT XXX. Kuesioner didistribusikan kepada 82 orang pegawai. Metode yang dipakai di penelitian ialah metode survei, bentuk penelitian yaitu deskriftif dan verifikatif. Kuesioner tersebut diuji memakai uji validitas juga reliabilitas. Skala likert digunakan sebelum dilakukan analisis dengan regresi berganda. Hal ini supaya tahu dampak dua variabel bebas yang digunakan terhadap satu variabel terikat. Hasil penelitian ini berdasarkan hasil uji tersebut menunjukkan bahwa semua indikator dinyatakan valid dan reliabel. Secara simultan kompetensi dan motivasi mempengaruhi positif juga signifikan pada kinerja pegawai XXX. Sedangkan secara parsial kompetensi mempengaruhi positif juga signifikan pada kinerja pegawai, serta motivasi mempengaruhi positif juga signifikan pada kinerja pegawai PT XXX.
\end{abstract}

Kata Kunci : Kompetensi, Motivasi dan Kinerja Pegawai

\section{PENDAHULUAN}

Sumber daya manusia ialah modal

paling besar pada organisasi seperti perusahaan. Oleh sebab itu, banyak perusahaan yang paling serius mendirikan dan pengembangan SDM. Organisasi yang efektif akan dibantu oleh SDM berkualitas. 
Sebaliknya, organisasi yang gagal karena faktor kinerja sumber daya manusia. Dengan demikian, ada korelasi antara keberuntungan ataupun kinerja organisasi dengan kinerja individual atau sumber daya manusia, kompetensi akan sangat berpengaruh kepada kinerja pegawai.

Kompetensi merupakan jenis keahlian, pengetahuan, pendidikan dan kemampuan untuk menjalankan suatu kegiatan yang efektif (Simamora, 2004). Kesuksesan organisasi ditentukan oleh mutu SDM melalui kompetensinya, kompetensi akan mendorong seseorang untuk memiliki kinerja terbaik dalam organisasi. Kompetensi, pengetahuan dan kemampuan untuk menangani pekerjaan dapat berpengaruh terhadap target yang diharapkan oleh perusahaan salah satunya dapat dilihat dari pengetahuan atau keahlian pegawai terhadap pekerjaan tersebut dapat menguasai pekerjaan dengan baik atau tidak. Standar kompetensi yang diharapkan oleh perusahaan yaitu sesuai dengan jabatan atau tanggungjawab yang diberikan pada pegawai tersebut. Data yang diperoleh dari departemen Sumber Daya Manusia (SDM) PT XXX pada tahun 2017, menunjukkan bahwa kompetensi pendidikan pegawai terbanyak pada status pendidikan S1 46,92\%, pendidikan SMA 36,9\%, pendidikan Diploma $15,50 \%$, pendidikan S2 $0,68 \%$ sedangkan dari data tersebut tidak terdapat pegawai dengan status pendidikan SMP dan SD. Ini menunjukkan bahwa kompetensi pegawai belum sesuai dengan harapan dari perusahaan dan menyebabkan tidak terselesaikannya target. PT XXX merupakan perusahaan dibidang real estate berupa penjualan tanah dan rumah, pengoperasian lapangan golf, country club, villa dan fasilitas resort lainnya. Berdasarkan pengamatan pada PT XXX diperoleh informasi masih banyak pegawai yang belum memahami pekerjaan seperti pada beberapa departemen misalnya seorang pegawai diminta untuk menyiapkan data kontraktor seperti membuat surat penawaran, surat perjanjian, kwitansi dan sebagainya, namun pegawai tersebut mengerjakan pekerjaan lain.

Menurut Simamora (2004), motivasi merupakan keinginan psikologis di arahkan seseorang menggapai suatu tujuan. Jika motivasi yang diberikan kepada pegawai itu tinggi, dapat membangkitkan semangat kerja yang berdampak pada meningkatnya kinerja pegawai dan sebaliknya (Septiyani, 2013). Pada PT XXX di mana motivasi pegawai dilaksanakan diarahkan pada pencapaian kinerja pegawai dalam kedisiplinan pegawai yang belum optimal berdasarkan data absensi pegawai yang menunjukan masih rendahnya disiplin kinerja pegawai. Dari data jumlah rata-rata absensi pegawai pada tahun 2015 keterlambatan tertinggi terjadi pada departemen Engineering dengan ratarata $20,91 \%$ dan pada tahun 2016 keterlambatan tertinggi terjadi pada departemen Estate 30,25\%, dibandingkan pada tahun 2015 - 2016 keterlambatan tertinggi terjadi dengan rata-rata $30,25 \%$ pada departemen Estate dengan persentasi 9,95\%. Rendahnya kompetensi dan motivasi pegawai diduga berpengaruh terhadap pencapaian target pegawai.

Berdasarkan data ketercapaian target PT XXX menetapkan target pada tahun 2015 pembuatan rumah sebanyak 45 (empat puluh lima) unit rumah, dengan persentase ketercapaian sebesar $75 \%$ artinya belum mencapai target. Sedangkan pada tahun 2016 target pembuatan rumah sebanyak 33 (tiga puluh tiga) unit dengan persentase ketercapaian sebesar $72,72 \%$, artinya belum mencapai target yaitu $100 \%$. Data tersebut 
menunjukkan bahwa perlunya usaha dari pegawai dalam mencapai target tersebut, melalui semangat dan minat kerja yang tinggi. Semangat kerja tinggi bisa meninggikan keberlanjutan organisasi juga perusahaan. Berdasarkan data dan uraian tersebut, bahwa faktor kompetensi dan motivasi diduga mempengaruhi kinerja pegawai, sehingga perlu dilakukan penelitian lebih lanjut. Berdasarkan latar belakang permasalahan tersebut, maka penulis tertarik mengambil judul "Pengaruh Kompetensi dan Motivasi terhadap Kinerja Pegawai pada PT XXX “.

\section{MATERI DAN METODE}

\section{Kompetensi}

Kompetensi jadi paling bermanfaat membantu organisasi menciptakan budaya kinerja tinggi, kompetensi sangat diperlukan pada tiap-tiap proses SDM, seleksi karyawan, manajemen kinerja, perencanaan, dan sebagainya. Hutapea dan Thoha (2008), kompetensi adalah kemampuan dan kemauan dalam melakukan sebuat kegiatan melalui kinerja juga efektif serta efisien menggapai keinginan perusahaan. Kompetensi merupakan bentuk kecakapan, kemampuan dan wewenang (Satori, 2007), sedangkan menurut Spancer (2007), kompetensi merupakan sifat yang melandasi seseorang berhubungan melalui efektivitas kinerja pribadi juga kegiatannya atau sifat mendasar seseorang yang memiliki hubungan sebab akibat melalui pertanda diajdikan acuan, efektif atau kinerja prima juga perior ditempat kerja atau pada situasi tertentu. Berdasarkan definisi tersebut, disimpulkan bahwa kompetensi merupakan kekuatan melakukan suatu pekerjaan juga kegiatan yang didasari juga kemampuan dan tugas yang relevan juga didorong oleh sikap kerja juga dituntut oleh kegiatan itu dan sesuai standar yang ditetapkan.

\section{Motivasi}

Motivasi bisa ditumbuhkan bila muncul kebutuhan ataupun tujuan baru. Apabila pemenuhan kebutuhan ialah kehendak manusia, juga keinginan bisa menjadi ketertarikan manusia juga organisasi. Motivasi ialah suatu hal yang paling penting diperhatikan perusahaan, karena ini sangat berpengaruh kinerja karyawan di lingkungan perusahaan. Menurut Simamora (2004), motivasi pegawai dapat dipengaruhi faktor minat, gaji yang diterima, kebutuhan akan rasa aman, hubungan antara pesonal dan kesempatan untuk bekerja. Sedangkan menurut Uno (2009), motivasi merupakan kekuatan didukung individu melaksanakan suatu untuk menggapai tujuan. Berdasarkan definisi tersebut, simpulan bahwa motivasi ialah dukungan psikologis yang menyebabkan intensitas arah dan karakteristik seseorang individu dalam melaksanakan suatu untuk menggapai tujuannya.

\section{Kinerja}

Kinerja ialah mengenai melaksanakan kegiatan dan tujuan yang digapai dari kegiatan tersebut. Kinerja bisa dilihat sebagai proses juga hasil kerja. Kinerja ialah sesuatu proses mengenai kegiatan berlangsung untuk menggapai tujuan kerja. Menurut Wibowo (2007), kinerja ialah pencapaian pekerjaan yang punya keterikatan kuat melalui tujuan strategi organisasi, kepuasan konsumen, memberi dukungan pada ekonomi. Dengan begitu kinerja fokus pada tujuan kerjanya. Sedangkan menurut Mangkunegara (2015), 
kinerja merupakan perolehan kerja secara mutu dan jumlah yang digapai oleh karyawan dalam melakukan kegiatannya sesuai dengan tanggung jawab diberi kepadanya. Kinerja ialah tindakan manusia pada suatu organisasi untuk memenuhi standar tindakan ditetapkan untuk memperoleh tujuan diinginkan. Berdasarkan definisi tersebut, disimpulkan jika kinerja ialah tujuan pekerjaan yang didapat dari fungsi kegiatan tertentu dalam waktu tertentu, yang punya keterikatan kuat dengan pencapaian strategis organisasi, kepuasan konsumen, juga memberi dukungan pada ekonomi.

\section{Kerangka Pemikiran}

Kinerja merupakan hasil pekerjaan yang mempunyai hubungan kuat dengan tujuan strategis organisasi, kepuasan konsumen dan memberikan kontribusi pada ekonomi (Wibowo : 2007). Kinerja pegawai dalam perspektif manajemen sumber daya manusia dapat dipandang sebagai prestasi kerja. Menurut Sudarmanto (2009), prestasi kerja seseorang tergantung dari motivasi kerja, kepuasan kerja, kompetensi, desain pekerjaan, komitmen, partisipasi dan sebagainya.

Menurut Umar (2005) prestasi kerja (P) seseorang karyawan tergantung dari kemampuan/kompetensi kerja (ability) dan motivasi (Motivation). Kompetensi SDM sangat penting, baik bagi eksekutif, manajer, maupun pekerja Wibowo (2007). Berdasarkan uraian tersebut maka disimpulkan Kompetensi dan Motivasi dapat berpengaruh terhadap kinerja Karyawan.

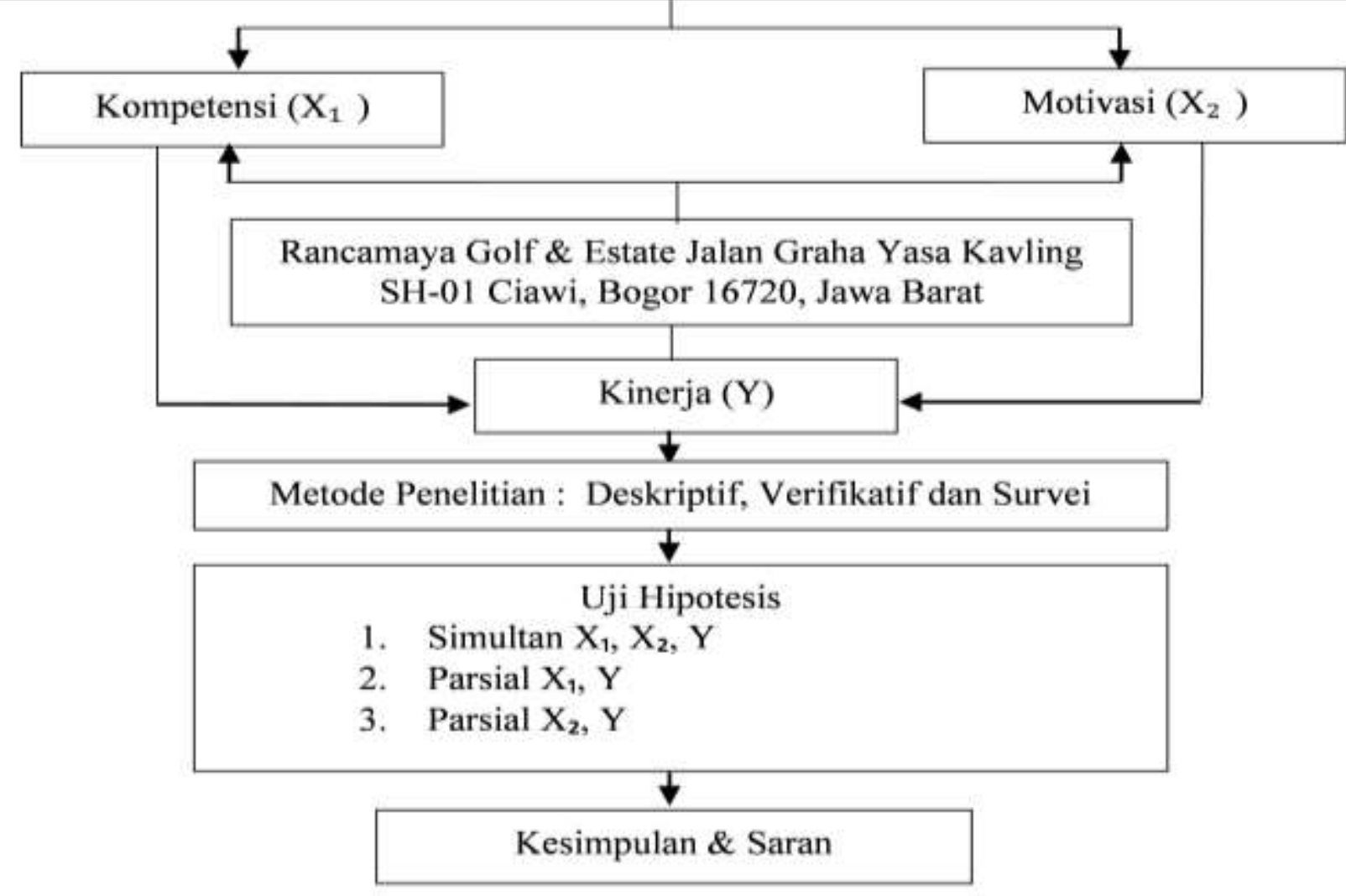

\section{Gambar 1. Kerangka Pemikiran}

Jenis penelitian yang dipergunakan pada penelitian ialah deskripif yaitu cara pada penelitian status sekelompok manusia, suatu objek, kondisi, suatu kelas peristiwa pemikiran, juga suatu kelas peristiwa di masa kini dan bentuk penelitian verifikatif 
menguji kebenaran (pengetahuan) pada bidang yang telah ada dan dipakai uji hipotesis memakai hitungan statistik (Hasan, 2009). Objek pada penelitian kali ini yaitu pegawai PT XXX. Jenis data pada penelitian ini yaitu data primer berupa data yang diperoleh dari jawaban responden melalui penyebaran kueisoner. Data sekunder diperoleh dari sumber keperpustakaan, hasil penelitian maupun media elektronik. Jumlah sampel yang diambil berjumlah 82 orang.
Operasionalisasi variabel penelitian adalah kumpulan definisi berdasarkan pada karakteristik yang diobservasi dari apapun yang didefinisikan atau mengganti konsep kalimat yang dapat diuraikan sesuai perilaku, dapat diamati, dapat diuji, serta dapat ditentukan kebenarannya. Semua operasionalisasi variabel penelitian ini kompetensi, motiivasi dan kinerja pegawai yaitu sebagai berikut.

Tabel 1. Operasionalisasi Variabel

\begin{tabular}{|c|c|c|}
\hline $\begin{array}{c}\text { Variabel / Konsep } \\
\text { Variabel }\end{array}$ & Dimensi & Indikator \\
\hline \multirow{3}{*}{$\begin{array}{l}\text { Kompetensi } X_{1} \\
\text { Kompetensi adalah } \\
\text { kemampuan dan } \\
\text { kemauan dalam } \\
\text { kegiatan efektif } \\
\text { efisien guna } \\
\text { menggapai keinginan } \\
\text { perusahaan. Hutapea } \\
\text { dan Thoha (2008) }\end{array}$} & $\begin{array}{l}\text { - Keterampilan }(\text { Skill }) \\
\text { Upaya melakukan kegiatan juga } \\
\text { tanggung jawab yang diberikan } \\
\text { perusahaan baik dan maksimal. }\end{array}$ & $\begin{array}{l}\text { - } \text { Bekerja sama } \\
\text { - } \text { Memecahkan masalah } \\
\text { - } \text { Memampuan berkomunikasi } \\
\quad \text { dengan maksiman pekerjaan } \\
\end{array}$ \\
\hline & $\begin{array}{l}\text { Pengetahuan (Knowledge) } \\
\text { Informasi yang dimiliki seorang } \\
\text { karyawan melakukan tugas sesuai bidang } \\
\text { yang ditekuni }\end{array}$ & $\begin{array}{l}\text { - } \text { Memahami pekerjaan } \\
\text { - } \text { pekerjaan } \\
\text { - Memiliki pengetahuan sesuai } \\
\text { bidang yang ditekuni } \\
\text { - Berpikir kreatif dalam } \\
\text { melaksanakan pekerjaan }\end{array}$ \\
\hline & $\begin{array}{l}\text { Sikap (Attitude) } \\
\text { Pola tingkah laku melakkukan pekerjaan } \\
\text { dan tanggung jawab dengan peraturan } \\
\text { perusahaan } \\
\text { Hutapea dan Thoha }(\mathbf{2 0 0 8 )}\end{array}$ & $\begin{array}{l}\text { - Hadir tepat waktu } \\
\text { - Melaksanakan pekerjaan tepat } \\
\text { waktu } \\
\text { - Mematuhi aturan terkait } \\
\text { pekerjaan } \\
\text { - Menyelesaikan pekerjaan sesuai } \\
\text { prosedur }\end{array}$ \\
\hline \multirow[t]{2}{*}{$\begin{array}{l}\text { Motivasi } X_{2} \\
\text { Motivasi ialah } \\
\text { kekuatan mendukung } \\
\text { pribadi melaksanakan } \\
\text { suatu guna menggapai } \\
\text { tujuan } \\
\text { Uno (2009) }\end{array}$} & $\begin{array}{l}\text { - Motivasi internal } \\
\text { Motivasi internal adalah motivasi yang } \\
\text { tumbuh pada pribadi tanpa dipengaruhi } \\
\text { oleh siapapun melaksanakan suatu } \\
\text { menggapai keinginan }\end{array}$ & $\begin{array}{l}\text { - Keinginan untuk memenuhi } \\
\text { kebutuhan hidup } \\
\text { - Keinginan untuk memperoleh } \\
\text { penghargaan } \\
\text { - Keinginan untuk memperoleh } \\
\text { pengakuan } \\
\text { - Keinginan untuk berkuasa } \\
\end{array}$ \\
\hline & $\begin{array}{l}\text { Motivasi eksternal } \\
\text { Motivasi eksternal adalah motivasi yang } \\
\text { datang dari luar diri seseorang dengan } \\
\text { harapan dapat mencapai sesuatu tujuan } \\
\text { yang dapat menguntungkan dirinya. } \\
\text { Uno (2009) }\end{array}$ & $\begin{array}{l}\text { - } \text { Kondisi lingkungan kerja } \\
\text { - } \text { Kompensasi yang memadai } \\
\text { - } \text { Adanya jaminan pekerjaan } \\
\text { - } \quad \text { Peraturan yang fleksibel }\end{array}$ \\
\hline $\begin{array}{l}\text { Kinerja Y } \\
\text { Kinerja perolehan } \\
\text { kerja bermutu dan } \\
\text { kuantitas yang digapai } \\
\text { karyawan melakukan } \\
\text { kegiatannya sesuai } \\
\text { tanggung jawab diberi }\end{array}$ & $\begin{array}{l}\text { - Kualitas kerja ialah beberapa pribadi } \\
\text { karyawan mengerjakan apa yang boleh } \\
\text { dikerjakan. }\end{array}$ & $\begin{array}{l}\text { - Mampu bekerja dengan teliti } \\
\text { - Mampu bekerja dengan cekatan, } \\
\text { cepat dan tepat } \\
\text { - Mampu mencapai standar yang } \\
\text { ditetapkan } \\
\text { - Cepat tanggap terhadap tugas } \\
\text { yang diberikan }\end{array}$ \\
\hline
\end{tabular}




\begin{tabular}{|c|c|c|}
\hline \multirow[t]{3}{*}{$\begin{array}{l}\text { kepadanya } \\
\text { Mangkunegara } \\
(\mathbf{2 0 1 5 )}\end{array}$} & $\begin{array}{l}\text { - Kuantitas kerja ialah beberapa lama } \\
\text { karyawan kerja pada suatu hari. Kuantitas } \\
\text { kerja bisa dilihat dari cepat kerja tiap } \\
\text { karyawan masing-masing. }\end{array}$ & $\begin{array}{l}\text { - Mampu bekerja mencapai target } \\
\text { - Memenuhi beban kerja yang telah } \\
\text { ditetapkan } \\
\text { - Mampu melebihi beban kerja } \\
\text { yang ditetapkan } \\
\text { - Mampu bekerja berdasarkan } \\
\text { efisiensi waktu yang ditentukan } \\
\text { perusahaan }\end{array}$ \\
\hline & $\begin{array}{l}\text { Pelaksanaan tugas yaitu berapa jauh } \\
\text { karyawan bisa melaksanakan pekerjaan } \\
\text { dengan akurat tidak ada salah. }\end{array}$ & $\begin{array}{l}\text { - } \text { Bekerja secara akurat dan tidak } \\
\text { ada kesalahan } \\
\text { - } \text { Bersedia memperbaiki } \\
\text { kesalahan } \\
\text { - Mampu mengambil keputusan } \\
\text { - Mampu berpartisipasi }\end{array}$ \\
\hline & $\begin{array}{l}\text { Tanggung Jawab terhadap pekerjaan yaitu } \\
\text { kesadaran akan kewajiban untuk } \\
\text { melaksanakan pekerjaan yang diberikan. } \\
\text { Mangkunegara (2015) }\end{array}$ & $\begin{array}{l}\text { Bertanggung jawab terhadap } \\
\text { apa yang dilakukan } \\
\text { Tidak menunda-nunda } \\
\text { pekerjaan } \\
\text { - Mengutamakan kepentingan } \\
\text { pekerjaan } \\
\text { - Memelihara alat, sarana dan } \\
\text { prasarana yang } \\
\text { dipertanggungjawabkan }\end{array}$ \\
\hline
\end{tabular}

\section{Uji Validitas dan Reliabilitas Instrumen}

Uji validitas dilakukan untuk mengetahui apakah alat ukur yang ada (disusun) valid atau tidak. Suatu indikator pada kuesioner diketahui valid apabila memiliki koefisien korelasi product moment melebihi atau sama dengan $0,30(\geq 0,30)$ yaitu nilai ketetapan yang menjadi acuan untuk pengambilan keputusan pada tahap uji validitas ini (Sugiyono, 2010). Berdasarkan pengujian instrument kepada tiga puluh (30) pegawai menunjukkan bahwa uji validitas terkait variabel bebas kompetensi dan motivasi, dan variabel terikat yakni kinerja pegawai bisa dikatakan valid, bisa di dilanjut ke uji reliabilitas.

Uji reliabilitas dilakukan untuk mengetahui samapai mana perolehan ukur terhadap item-item pertanyaan apakah tetap sama jika dilaksanakan pengukuran dua atau lebih pada gejala yang sama dengan alat ukur sama. Menurut Umar (2008) Kriteria suatu instrumen penelitian dikatakan reliabel dengan teknik ini, yaitu apabila reliabilitas instrumen rhitung $\geq 0,6$. Hasil perhitungan kedua uji menggunakan SPSS 20.0, Berdasarkan pengujian instrument penelitian kepada tiga puluh (30) pegawai menunjukkan bahwa dari seluruh variabel kompetensi, motivasi dan kinerja pegawai diperoleh hasil seluruh item reliabel karena memiliki Cronbach Alpha > 0,6.

\section{Metode Analisis}

Analisis regresi linier berganda merupakan metode analisis yang digunakan bila variabel terikat disebabkan lebih dari satu faktor. Analisis dipakai agar tahu dampak kompetensi dan motivasi pada kinerja pegawai. Adapun persamaan umum regresinya sebagai berikut:

$\mathrm{Y}=\mathrm{a}+\beta_{1} \mathrm{X}_{1}+\beta_{2} \mathrm{X}_{2}+\varepsilon$

Keterangan :

$$
\begin{array}{ll}
\mathrm{Y} & =\text { Kinerja pegawai } \\
\mathrm{a} & =\text { Konstanta } \\
\beta & =\text { Koefisien regresi } \\
\mathrm{X}_{1} & =\text { Kompetensi }
\end{array}
$$




$$
\begin{array}{ll}
\mathrm{X}_{2} & =\text { Motivasi } \\
\varepsilon & =\text { Faktor lain di luar penelitian }
\end{array}
$$

Hipotesis penelitian akan digunakan uji statistik dengan model penelitian terdapat pada Gambar 2 berikut.

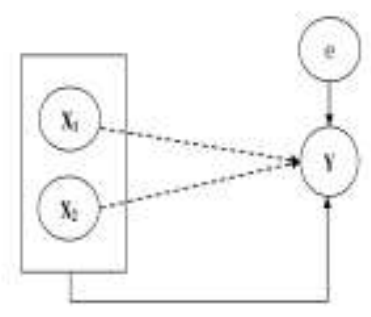

\section{Gambar 2. Hubungan Antar Variabel Penelitian}

Keterangan :

$=$ Pengaruh parsial

$=$ Pengaruh simultan

$=$ Pengaruh error variabel lain di luar penelitian

\section{Pengujian Hipotesis}

Untuk mengetahui kebenaran dari perhitungan analisis korelasi, maka diperlukan pengujian hipotesis nol (H0) dan hipotesis alternatif (Ha). Maka digunakan uji $-F$ dan Uji -t. Pengujian ini akan menggunakan distribusi $\mathrm{t}$, dengan keyakinan (1- $\alpha$ ) sebesar $95 \%$ dan derajat kebebasan sebesar n-5-1 untuk menguji apakah hipotesis diterima atau ditolak.

\section{HASIL DAN PEMBAHASAN}

\section{Karakteristik Pegawai}

Pegawai PT XXX sebagian besar yaitu laki-laki sebanyak 52 orang atau $63 \%$ karena PT XXX membutuhkan banyak tenaga dan keterampilan laki-laki dalam operasional lapangan seperti WTP (Water Treatment Plant), housing dan utillities, sedangkan perempuan bekerja pada bagian operasional office. Sebagian besar pegawai berusia $>30$ tahun dengan jumlah 28 orang atau sebesar 34\%, hal ini menunjukkan karena rentang usia tersebut pegawai sudah memiliki pengalaman dalam bekerja dan pendidikan terakhir pegawai sebagian besar adalah SMK sederajat dengan jumlah 43 orang atau sebesar 52\%, karena kurikulum pendidikan SMK adalah siap kerja dan lebih banyak dibutuhkan untuk pegawai untuk di lapangan. Berdasarkan rekapitulasi karakteristik pegawai, kesimpulannya bahwa mayoritas pegawai PT XXX adalah laki-laki berusia $>30$ tahun dengan pendidikan terakhir pegawai adalah SMK sederajat.

Adapun rekapitulasi tanggapan pegawai terhadap kompetensi, motivasi dan kinerja pegawai PT XXX antara lain :

- Kompetensi

Adapun rekapitulasinya adalah :

\begin{tabular}{|c|c|c|c|c|}
\hline No & Pernyataan & $\begin{array}{l}\text { Rata-rata } \\
\text { Penilaian } \\
\text { Pegawai }\end{array}$ & Kategori & Interpretasi \\
\hline 1 & Bekerja sama & 3,89 & Baik & $\begin{array}{l}\text { Kerja sama tim dalam penyusunan target } \\
\text { perencanaan dan pertemuan setiap bulan sebagai } \\
\text { evaluasi }\end{array}$ \\
\hline 2 & Memecahkan masalah & 3,67 & Baik & $\begin{array}{l}\text { Pembentukan tim kerja untuk dimintai saran dan } \\
\text { masukan dalam memecahkan masalah terkait } \\
\text { tidak tidak tercapainya target }\end{array}$ \\
\hline 3 & $\begin{array}{l}\text { Kemampuan } \\
\text { berkomunikasi }\end{array}$ & 3,58 & Baik & $\begin{array}{l}\text { Penyampaian pendapat dalam pertemuan yang } \\
\text { dilakukan setiap bulan }\end{array}$ \\
\hline 4 & $\begin{array}{l}\text { Melaksanakan pekerjaan } \\
\text { dengan maksimal }\end{array}$ & 3,57 & Baik & $\begin{array}{l}\text { Pekerjaan maksimal dalam pekerjaan proyek } \\
\text { pembangunan rumah }\end{array}$ \\
\hline 5 & Memahami pekerjaan & 3,28 & $\begin{array}{l}\text { Cukup } \\
\text { Baik }\end{array}$ & $\begin{array}{l}\text { Memahami pekerjaan sesuai SOP (Standard } \\
\text { Operating Procedure) }\end{array}$ \\
\hline
\end{tabular}

Tabel 2. Rekapitulasi Tanggapan Pegawai Teehadap Kompetensi 


\begin{tabular}{|c|c|c|c|c|}
\hline 6 & $\begin{array}{l}\text { Memahami aturan } \\
\text { terkait pekerjaan }\end{array}$ & 3,43 & Baik & $\begin{array}{l}\text { Memahami aturan pekerjaan terkait instruksi kerja } \\
\text { dan SOP (Standard Operating Procedure) }\end{array}$ \\
\hline 7 & $\begin{array}{l}\text { Memiliki pengetahuan } \\
\text { sesuai bidang yang } \\
\text { ditekuni }\end{array}$ & 3,86 & Baik & $\begin{array}{l}\text { Kompetensi pendidikan dipersyaratkan setiap } \\
\text { bidang pekerjaan dan ditingkatkan dengan cara } \\
\text { melakukan pelatihan }\end{array}$ \\
\hline 8 & $\begin{array}{l}\text { Berpikir kreatif dalam } \\
\text { melaksanakan pekerjaan }\end{array}$ & 3,53 & Baik & $\begin{array}{l}\text { Pegawai dimintai saran, ide dan masukan dalam } \\
\text { pertemuan evaluasi pencapaian target perusahaan }\end{array}$ \\
\hline 9 & Hadir tepat waktu & 3,69 & Baik & $\begin{array}{l}\text { Pegawai hadir tepat waktu sesuai jadwal kerja } \\
\text { yang ditetapkan perusahaan }\end{array}$ \\
\hline 10 & $\begin{array}{l}\text { Melaksanakan pekerjaan } \\
\text { tepat waktu }\end{array}$ & 3,61 & Baik & $\begin{array}{l}\text { Proyek pembangunan rumah sesuai jadwal kerja } \\
\text { dan target yang ditetapkan }\end{array}$ \\
\hline 11 & $\begin{array}{l}\text { Mematuhi aturan terkait } \\
\text { pekerjaan }\end{array}$ & 3,46 & Baik & $\begin{array}{l}\text { Memahami aturan penggunaan APD (Alat } \\
\text { Pelindung Diri) dan bekerja sesuai SOP }\end{array}$ \\
\hline 12 & $\begin{array}{l}\text { Menyelesaikan } \\
\text { pekerjaan sesuai } \\
\text { prosedur }\end{array}$ & 3,79 & Baik & $\begin{array}{l}\text { Menyelesaikan pekerjaan sesuai prosedur terkait } \\
\text { proyek pembangunan rumah }\end{array}$ \\
\hline \multicolumn{2}{|c|}{$\begin{array}{l}\text { Rata-rata penilaian pegawai } \\
\text { terhadap kompetensi }\left(\mathbf{X}_{1}\right)\end{array}$} & 3,61 & Baik & \\
\hline
\end{tabular}

Sumber : Data Primer Diolah, 2017

Berdasarkan hasil dari Tabel tersebut dapat dilihat bahwa penilaian indikator variabel kompetensi memiliki nilai rata-rata sebesar 3,61, termasuk dalam kategori baik. Hal ini menunjukkan bahwa pegawai PT XXX memiliki kompetensi yang baik berupa pengetahuan, keterampilan dan sikap yang diperlukan sehingga pegawai dapat melaksanakan tugas jabatannya secara professional, effective dan efficient. Pernyataan tersebut sesuai dengan penelitian Fadhil (2016) bahwa pengetahuan berperan penting dalam menjalankan tugas pokok dan fungsi organisasi, keterampilan pegawai yang terampil dan produktif memanfaatkan segala kebutuhan dengan menfaatkan sumber daya yang ada memberikan nilai tambah dalam mengembangkan kemajuan organisasai, serta sikap yang baik dimiliki pegawai menggambarkan komitmen dan disiplin kerja dalam menyelesaikan aktivitas kerjanya.

- Motivasi

Adapun rekapitulasinya adalah :

Tabel 3. Rekapitulasi Tanggapan Pegawai Terhadap Motivasi

\begin{tabular}{|c|c|c|c|c|}
\hline No & Pernyataan & $\begin{array}{l}\text { Rata-rata } \\
\text { Penilaian } \\
\text { Pegawai }\end{array}$ & Kategori & Interpretasi \\
\hline 1 & $\begin{array}{l}\text { Keinginan untuk } \\
\text { memenuhi hidup }\end{array}$ & 4,19 & $\begin{array}{l}\text { Sangat } \\
\text { Tinggi }\end{array}$ & $\begin{array}{l}\text { Bekerja untuk memenuhi kebutuhan mulai dari } \\
\text { kebutuhan primary, secondary dan tertiary }\end{array}$ \\
\hline 2 & $\begin{array}{l}\text { Keinginan untuk } \\
\text { memperoleh } \\
\text { penghargaan }\end{array}$ & 3,47 & Tinggi & $\begin{array}{l}\text { Penghargaan yang diberikan perusahaan membuat } \\
\text { pekerjaan diapresiasi nyata }\end{array}$ \\
\hline 3 & $\begin{array}{l}\text { Keinginan untuk } \\
\text { memperoleh pengakuan }\end{array}$ & 3,06 & $\begin{array}{l}\text { Cukup } \\
\text { Tinggi }\end{array}$ & $\begin{array}{l}\text { Bekerja agar mendapat penilaian yang baik dan } \\
\text { dipromosikan ke jabatan yang lebih tinggi }\end{array}$ \\
\hline 4 & $\begin{array}{l}\text { Keinginan untuk } \\
\text { berkuasa }\end{array}$ & 2,93 & $\begin{array}{l}\text { Cukup } \\
\text { Tinggi }\end{array}$ & $\begin{array}{l}\text { Keinginan pegawai untuk kekuasaan dan jabatan } \\
\text { rendah, karena pegawai bekerja untuk memenuhi } \\
\text { kebutuhan }\end{array}$ \\
\hline 5 & $\begin{array}{l}\text { Kondisi lingkungan } \\
\text { kerja }\end{array}$ & 3,67 & Tinggi & $\begin{array}{l}\text { Lingkungan kerja yang nyaman, aman, berish dan } \\
\text { memadai mendukung suasana kerja menjadi lebih } \\
\text { baik }\end{array}$ \\
\hline 6 & $\begin{array}{l}\text { Kompensasi yang } \\
\text { memadai }\end{array}$ & 4,01 & Tinggi & $\begin{array}{l}\text { Kompensasi yang didapat pegawau memadai dan } \\
\text { layak sesuai dengan posisi atau jabatannya }\end{array}$ \\
\hline
\end{tabular}




\begin{tabular}{|c|l|c|c|l|}
\hline 7 & $\begin{array}{l}\text { Adanya jaminan } \\
\text { pekerjaan }\end{array}$ & 3,87 & Tinggi & $\begin{array}{l}\text { Jaminan berupa asuransi kesehatan, asuransi } \\
\text { kecelakaan kerja dan jaminan hari tua }\end{array}$ \\
\hline 8 & Peraturan yang fleksibel & 3,51 & Tinggi & $\begin{array}{l}\text { Perusahaan memberikan keleluasaan terhadap } \\
\text { pegawai berupa peraturan kerja yang fleksibel }\end{array}$ \\
\hline $\begin{array}{l}\text { Rata-rata penilaian pegawai } \\
\text { terhadap motivasi }\left(\mathbf{X}_{2}\right)\end{array}$ & 3,58 & Tinggi & \\
\hline
\end{tabular}

Sumber : Data Primer Diolah, 2017

Berdasarkan Tabel tersebut dapat dilihat bahwa penilaian indikator variabel motivasi memiliki nilai rata-rata sebesar 3,58, termasuk dalam kategori tinggi. Hal ini menunjukkan bahwa pegawai PT XXX punya motivasi tinggi dalam bekerja, karena tiap-tiap pekerjaan bidang apa saja membutuhkan kemampuan dan kecakapan pribadi, juga butuh motivasi diri seseorang hingga kegiatan dilaksanakan bisa sukses dengan baik. Hal tersebut sejalan dengan pernyataan dari Siagian (2003), motivasi yang tepat membuat para pegawai terdotong melakukan maksimal mungkin dalam melakukan tugasnya, serta penelitian dari Cahyono dan Hamid (2013), bahwa dengan adanya motivasi dapat mendorong pegawai untuk meningkatkan kinerjanya yang diharapkan dapat meningkatkan kemajuan perusahaan.

- Kinerja Pegawai

Adapun rekapitulasinya adalah :

Tabel 4. Rekapitulasi Tanggapan Terhadap Kinerja Pegawai

\begin{tabular}{|c|c|c|c|c|}
\hline No & Pernyataan & $\begin{array}{c}\text { Rata-rata } \\
\text { Penilaian } \\
\text { Pegawai }\end{array}$ & Kategori & Interpretasi \\
\hline 1 & $\begin{array}{l}\text { Mampu bekerja dengan } \\
\text { teliti }\end{array}$ & 3,81 & Baik & $\begin{array}{l}\text { Bekerja dengan tepat waktu, detail dan sesuai } \\
\text { target yang ditetapkan }\end{array}$ \\
\hline 2 & $\begin{array}{l}\text { Mampu bekerja dengan } \\
\text { cekatan, cepat dan tepat }\end{array}$ & 3,72 & Baik & $\begin{array}{l}\text { Tidak memunda-nunda pekerjaan, dan lotalitas } \\
\text { tinggi }\end{array}$ \\
\hline 3 & $\begin{array}{l}\text { Mampu mencapai } \\
\text { standar yang ditetapkan }\end{array}$ & 3,46 & Baik & Memenuhi target penjualan \\
\hline 4 & $\begin{array}{l}\text { Cepat tanggap terhadap } \\
\text { tugas yang diberikan }\end{array}$ & 3,59 & Baik & $\begin{array}{l}\text { Memberikan pelayanan kepada pelanggan dan } \\
\text { mengatasi permasalahan }\end{array}$ \\
\hline 5 & $\begin{array}{l}\text { Mampu bekerja } \\
\text { mencapai target }\end{array}$ & 3,40 & Baik & $\begin{array}{l}\text { Mencapai target penjualan untuk memnuhi laba } \\
\text { maksimal }\end{array}$ \\
\hline 6 & $\begin{array}{l}\text { Memenuhi beban kerja } \\
\text { yang ditetapkan }\end{array}$ & 3,32 & $\begin{array}{l}\text { Cukup } \\
\text { Baik }\end{array}$ & Bekerja melebihi waktu yang ditetapkan \\
\hline 7 & $\begin{array}{l}\text { Mampu melebihi beban } \\
\text { kerja yang ditetapkan }\end{array}$ & 3,23 & $\begin{array}{l}\text { Cukup } \\
\text { Baik }\end{array}$ & $\begin{array}{l}\text { Melakukan pekerjaan bukan dari job desk } \\
\text { pegawai bersangkutan }\end{array}$ \\
\hline 8 & $\begin{array}{l}\text { Mampu bekerja } \\
\text { berdasarkan efisiensi } \\
\text { yang ditentukan } \\
\text { perusahaan }\end{array}$ & 3,69 & Baik & $\begin{array}{l}\text { Bekerja cepat, tepat waktu, tidak menunda } \\
\text { pekerjaan }\end{array}$ \\
\hline 9 & $\begin{array}{l}\text { Bekerja secara akurat } \\
\text { tanpa ada kesalahan }\end{array}$ & 3,54 & Baik & $\begin{array}{l}\text { Bekerja dengan teliti, cermat, berhati-hati dan } \\
\text { fokus pada kepuasan pelanggan }\end{array}$ \\
\hline 10 & $\begin{array}{l}\text { Bersedia memperbaiki } \\
\text { kesalahan }\end{array}$ & 4,13 & Baik & $\begin{array}{l}\text { Berusaha dengan baik dan tidak menyerah } \\
\text { apabila ada kesalahan }\end{array}$ \\
\hline 11 & $\begin{array}{l}\text { Mampu mengambil } \\
\text { keputusan }\end{array}$ & 3,75 & Baik & $\begin{array}{l}\text { Pegawai dimintai masukannya terkait kinerja dan } \\
\text { evaluasi dalam pertemuan rutin }\end{array}$ \\
\hline 12 & Mampu berpartisipasi & 4,14 & Baik & $\begin{array}{l}\text { Keikutsertaan pegawai dalam pertemuan dan } \\
\text { partisipasi dalam penyelesaian masalah }\end{array}$ \\
\hline 13 & $\begin{array}{l}\text { Bertanggung jawab } \\
\text { terhadap apa yang }\end{array}$ & 3,98 & Baik & $\begin{array}{l}\text { Penentuan pegawai yang bertanggung jawab } \\
\text { dalam pekerjaan atau PIC }\end{array}$ \\
\hline
\end{tabular}




\begin{tabular}{|c|c|c|c|c|}
\hline & dilakukan & & & \\
\hline 14 & $\begin{array}{l}\text { Tidak menunda-nunda } \\
\text { pekerjaan }\end{array}$ & 4,06 & Baik & Bekerja sesuai target, fokus dan cepat \\
\hline 15 & $\begin{array}{l}\text { Mengutamakan } \\
\text { kepentingan pekerjaan }\end{array}$ & 3,81 & Baik & $\begin{array}{l}\text { Tidak mengambil keuntungan secara pribadi } \\
\text { dalam bekerja }\end{array}$ \\
\hline 16 & $\begin{array}{l}\text { Memelihara alat, sarana } \\
\text { dan prasarana yang } \\
\text { dipertanggungjawabkan }\end{array}$ & 3,96 & Baik & $\begin{array}{l}\text { Tidak merusak, mengotori, merawat dan } \\
\text { bertangung jawab penuh terhadap penggunaan } \\
\text { peralatan kerja }\end{array}$ \\
\hline \multicolumn{2}{|c|}{$\begin{array}{l}\text { Rata-rata penilaian pegawai } \\
\text { terhadap kinerja (Y) }\end{array}$} & 3,72 & Baik & \\
\hline
\end{tabular}

Sumber : Data Primer Diolah, 2017

Berdasarkan Tabel diatas tersebut dapat dilihat bahwa penilaian indikator variabel kinerja memiliki nilai rata-rata sebesar 3,72, termasuk dalam kategori baik. Hal tersebut menunjukkan bahwa kinerja pegawai pada umumnya sudah baik dilihat dari ketercapaian target perusahaan yang mencapai 72,72\% meskipun belum mampu mencapai target yang ditetapkan perusahaan yakni $100 \%$.

\section{Hasil Estimasi Persamaan Regresi}

Bentuk persamaan dihitung dengan menggunakan analisis regresi linear berganda. Adapun persamaan tersebut menunjukkan pengaruh kompetensi dan motivasi terhadap kinerja pegawai. Adapun hasil perhitungan bentuk hubungan fungsional dengan menggunakan analisis regresi linear berganda:

$$
Y=16,933+0,109 X_{1}+1,168 X_{2}+e .
$$

Berdasarkan persamaan tersebut diketahui Koefisien regresi kompetensi $\left(\mathrm{X}_{1}\right)$ $=0,109$ bernilai positif berarti semakin tinggi tingkat kompetensi maka semakin tinggi kinerja pegawai (Y) dan $\mathrm{X}_{2}$ tetap. Koefisien regresi motivasi $\left(\mathrm{X}_{2}\right)=1,168$ bernilai positif berarti semakin tinggi tingkat motivasi maka semakin tinggi kinerja pegawai (Y) dan $\mathrm{X}_{1}$ tetap.

\section{Pengujian Korelasi Berganda}

Analisis korelasi berganda dipakaiagar tahu hubungan antara variabel saat kompetensi $\left(\mathrm{X}_{1}\right)$, motivasi $\left(\mathrm{X}_{2}\right)$ dengan variabel kinerja pegawai (Y). diketahui nilai $\mathrm{R}$ adalah 0,662 yang berada pada kategori kuat $(0,600-0,799)$ menggambarkan jika hubungan antara kompetensi juga motivasi pada kinerja pegawai memiliki hubungan yang kuat. Hal ini menunjukkan bahwa hubungan kompetensi dan motivasi terhadap kinerja pegawai adalah kuat. Sejalan dengan penelitan Warningsih (2010) dan Mohklas (2015), bahwa hubungan antara kompetensi juga motivasi pada kinerja memiliki hubungan yang kuat. Sama halnya dengan penelitian Yuliana (2018), hubungan kompetensi serta motivasi terhadap kinerja memiliki hubungan yang kuat.

\section{Pengujian Koefisien Determinasi}

Analisis koefisien determinasi dipakai agar tahu berapa besar persentase sumbangan pengaruh kompetensi dan motivasi terhadap kinerja pegawai. Diketahui bahwa hasil $R$ Square sebesar 0,438 atau $43,8 \%$. Hal ini menunjukkan bahwa persentase sumbangan pengaruh variabel kompetensi juga motivasi pada kinerja pegawai $43,8 \%$ yang sisa $56,2 \%$ dipengaruhi elemen lain seperti kemampuan, pengalaman kerja, pendidikan, kondisi fisik pekerjaan (Handoko, 2015). Sesuai dengan penelitian dari Pratama (2012), Rahayu (2017) dan Sutedjo (2018), bahwa sekitar $40 \%$ dampak kompetensi juga motivasi pada 
kinerja pegawai, sedangkan sisanya $60 \%$ dipengaruhi elemen lain.

\section{Pengujian Secara Simultan (Uji F)}

Untuk membuktikan bersama-sama / simultan kompetensi dan motivasi terhadap kinerja pegawai mempergunakan statistik uji-F. Dan dari hasil perhitungan diperoleh bahwa $F_{\text {hitung }}$ sebesar 30,828 dan nilai $F_{\text {tabel }}$ untuk $\alpha=0,05$ dengan derajat kebebasan $\mathrm{V}_{1}$ = 3-1=2 dan $\mathrm{V}_{2}=82-2-1=79$ sebesar 3,11 maka dapat dilihat bahwa $F_{\text {hitung }}$ lebih besar dari $F_{\text {tabel }}(30,828>3,11)$ maka dapat disimpulkan bahwa Ho ditolak dan $\mathrm{Ha}$ diterima artinya dengan tingkat kepercayaan 95\% variabel independen kompetensi $\left(\mathrm{X}_{1}\right)$ dan motivasi $\left(\mathrm{X}_{2}\right)$ berpengaruh positif dan signifikan secara simultan (bersama-sama) terhadap kinerja pegawai (Y). Hal tersebut sejalan dengan penelitian yang dilakukan Rosidah (2004) dan Muryanto (2011) yang memperlihatkan secara simultan kompetensi dan motivasi pengaruhi positif signifikasi terhadap kinerja pegawai. Aqbar (2017) dalam penelitiannya bahwa kompetensi dan motivasi berpengaruh positif dan signifikan secara simultan terhadap kinerja.

\section{Pengujian Secara Parsial (Uji-t)}

Berdasarkan perhitungan diperoleh hasil pengujian setiap variabel bebas (kompetensi dan motivasi) tehadap kinerja pegawai yaitu :

- Pengaruh Kompetensi $\left(\mathrm{X}_{1}\right)$ Kinerja Pegawai (Y)
Hasil perhitungan pada tabel thitung pada variabel kompetensi $\left(\mathrm{X}_{1}\right)$ sebesar 1,694 dan nilai tabel untuk $\alpha=0,05$ dengan derajat kebebasan 82-2-1=79 sebesar 1,664 berarti $t_{\text {hitung }}>t_{\text {tabel }}(1,694>1,664)$. Maka $\mathrm{H}_{0}$ ditolak dan Ha diterima, kompetensi $\left(\mathrm{X}_{1}\right)$ mempunyai pengaruhi positif juga signifikasi pada kinerja pegawai (Y). Hal ini seperti yang dikemukakan oleh Indrawati (2017), Setiawan (2017) dan Calista (2016) bahwa kompetensi berpengaruh secara positif dan signifikan terhadap kinerja pegawai.

- Pengaruh Motivasi $\left(\mathrm{X}_{2}\right)$ Kinerja Pegawai (Y)

Hasil perhitungan pada tabel $t_{\text {hitung }}$ pada variabel kompetensi $\left(\mathrm{X}_{1}\right)$ sebesar 7,493 dan nilai tabel untuk $\alpha=0,05$ dengan derajat kebebasan 82-2-1=79 sebesar 7,493 berarti $t_{\text {hitung }}>t_{\text {tabel }}(7,493>1,664)$. Maka $\mathrm{H}_{0}$ ditolak dan $\mathrm{Ha}$ diterima, artinya motivasi $\left(\mathrm{X}_{2}\right)$ mempunyai pengaruh positif dan signifikan terhadap kinerja pegawai (Y). Hal ini seperti yang dikemukakan oleh Cahyono dan Hamid (2013), Irawati dan Mustakim (2012) dan Pranata (2015) bahwa motivasi berpengaruh secara positif dan signifikan terhadap kinerja pegawai.

Berdasarkan hasil dari penilaian pegawai mengenai pengaruh kompetensi dan motivasi terhadap kinerja pegawai pada PT $\mathrm{XXX}$, berikut ini rekapitulasi dapat terlihat pada tabel dibawah ini.

Tabel 5. Rekapitulasi Hasil Uji Terhadap Koefisien Regresi Secara Parsial

\begin{tabular}{|c|c|c|c|c|}
\hline No & $\begin{array}{c}\text { Variabel } \\
\text { Independen }\end{array}$ & t tabel & t hitung & Keterangan \\
\hline 1 & Kompetensi $\left(\mathrm{X}_{1}\right)$ & 1,664 & 1,694 & Berpengaruh positif dan signifikan \\
\hline 2 & Motivasi $\left(\mathrm{X}_{2}\right)$ & 1,664 & 7,493 & Berpengaruh positif dan signifikan \\
\hline
\end{tabular}

Sumber : Data Primer Diolah, 2017 
Berdasarkan Tabel 5 di atas, dapat diketahui bahwa hasil uji koefisien regresi secara parsial antara variabel kompetensi dan motivasi masing-masing berpengaruh terhadap kinerja pegawai. Adapun variabel terbesar yang mempengaruhi kinerja pegawai $(\mathrm{Y})$ adalah motivasi $\left(\mathrm{X}_{2}\right)$ sebesar 7,493 serta kontribusi terkecil adalah kompetensi $\left(\mathrm{X}_{1}\right)$ yaitu sebesar 1,694. Jika dibandingkan kedua variabel tersebut yang paling besar yaitu pada variabel motivasi $\left(\mathrm{X}_{2}\right)$, hal ini karena pegawai memiliki semangat yang tinggi dalam bekerja dengan alasan seperti penuhi kebutuhan hidup maupun karena lingkungan kerja yang kondusif, adanya kompensasi yang layak, jaminan pekerjaan serta peraturan kerja yang fleksibel, dimana hal tersebut didukung dengan rata-rata kenaikan tingkat absensi pada masing-masing departemen kecil.

\section{KESIMPULAN DAN IMPLIKASI}

Dari hasil penelitian dan pembahasan disimpulkan bahwa :

- Kompetensi pegawai pada PT XXX sudah baik, indikator tertinggi adalah bekerja sama dan indikator terendah adalah memahami pekerjaan.

- Motivasi kerja pegawai pada PT XXX sudah tinggi, indikator tertinggi adalah keinginan untuk dapat hidup dan indikator terendah adalah keinginan untuk berkuasa.

- Kinerja pegawai pegawai pada PT XXX sudah baik, indikator tertinggi adalah bersedia memperbaiki kesalahan dan indikator terendah adalah memenuhi beban kerja ditetapkan.

- Dari hasil pengujian secara simultan (Uji F) bahwa kompetensi dan motivasi simultan pengaruhi positif dan signifikasi pada kinerja pegawai.
- Dari hasil pengujian secara parsial (Uji t) bahwa kompetensi dan motivasi secara parsial pengaruhi positif juga signifikasi pada kinerja pegawai.

Berdasarkan hasil penelitian, ada beberapa masukan mengenai kompetensi juga motivasi pada kinerja pegawai, antara lain :

- Bagi PT XXX, penelitian ini memiliki beberapa saran yang disampaikan sebagai bahan evaluasi dan perbaikan, yaitu sebagai berikut :

- Kompetensi pegawai pada PT XXX sudah baik, dengan indikator terendah adalah memahami pekerjaan PT XXX sebaiknya terus memberikan pemahaman mengenai pekerjaan kepada para pegawai melalui sosialisasi prosedur dan distribusi dokumen terkait prosedur kepada para pegawai. PT XXX.

- Motivasi pegawai untuk bekerja pada PT XXX tinggi, dengan indikator terendah adalah keinginan untuk berkuasa (jenjang karir). Dalam upaya meningkatkan kebutuhan berkuasa (pengembangan) pegawai terhadap suatu jabatan, hendaknya pimpinan menciptakan keadaan kerja yang baik dan memberikan kesempatan untuk promosi. Dengan demikian dapat memungkinkan pegawai meningkatkan semangat kerjanya untuk mencapai kebutuhan akan kedudukannya.

- Kinerja pegawai PT XXX dalam bekerja sudah baik, dengan indikator terendah adalah memenuhi beban kerja telah ditetapkan. Untuk mengatasi beban kerja yang tinggi perusahaan perlu menentukan prioritas yaitu menempatkan tugas 
berdasarkan urutan terpenting, menetapkan waktu pelaksanaan dan PIC (pegawai yang bertanggung jawab), hal ini akan membantu dalam mengetahui tingkat kepentingan dan urgensi setiap tugas untuk mengurangi stress dalam bekerja. Sementara itu untuk memenuhi beban kerja telah ditetapkan perusahaan, perusahaan harus tetap memperhatikan kesejahteraan pegawai salah satunya dengan memberikan penghargaan, insentif dan bonus sebagai upaya meningkatkan produktivitas pegawai dalam memenuhi beban kerja yang tinggi.

- Bagi yang akan melakukan penelitian lanjutan mengenai kinerja pegawai hendaknya melakukan penelitian pada faktor-faktor lain yang dapat mempengaruhi kinerja, seperti kemampuan, pengalaman kerja, pendidikan, dan kondisi fisik pekerjaan.

\section{UCAPAN TERIMA KASIH}

Ucapan terima kasih kepada PT XXX dan Universitas Djuanda Bogor serta semua pihak yang terkait dalam penelitian ini.

\section{DAFTAR PUSTAKA}

Aqbar, Nabila Nur Rizky, 2017. Pengaruh Kompetensi dan Motivasi terhadap Kinerja Karyawan pada PT. Suryaputra Sarana Bandung. Jurnal Ekonomi. Fakultas EkonomiUniversitas Pasundan. Bandung. Vol. 4 No.3. Hal 120-130.

Cahyono, Budhi, 2010. Peningkatan Performa Perusahaan Melalui Integrasi Supply Chain pada Industri Kecil di Semarang. Jurnal Ekonomi Bisnis. Fakultas Ekonomi-Universitas
Islam Sultan Agung. Semarang. Hal 110.

Cahyono, Wandra Agus dan Djamhur Hamid, 2016. Pengaruh Gaya Kepemimpinan dan Motivasi Kerja Terhadap Kinerja Karyawan (Studi pada PT. Victory International Futures Malang). Jurnal Administrasi Bisnis. Universitas Brawijaya. Malang. Vol. 33. No. 2. Hal 2-10.

Calista, Natasha, 2016. Pengaruh Kompetensi SDM Terhadap Kinerja Karyawan pada PT. Tresnamuda Sejati Cabang Surabaya. Jurnal Agora. Universitas Kristen Petra. Surabaya. Vol. 4. No. 2. Hal 45-50.

Fadhil, Muhammad, 2016. Pengaruh Kompetensi Sumber Daya Manusia Terhadap Kinerja Pegawai pada Balai Latihan Kerja Industri Makasar. Jurnal Perspektif. Universitas Muslim Indonesia. Makasar. p-ISSN:23550538. Vol. 1 No. 1. Hal 70-80.

Handoko, T Hani, 2015. Manajemen. Edisi 2. BPFE. Yogyakarta.

Hasan. Iqbal, 2009. Pokok-pokok Materi Metodologi Penelitian dan Aplikasinya. Ghalia Indonesia. Jakarta.

Hasibuan Malayu S.P, 2010. Manajemen Sumber Daya Manusia. Bumi Aksara. Jakarta.

Hutapea, Parulian dan Nurianna Thoha, 2008. Kompetensi Komunikasi Plus : Teori, Desain Kasus dan Penerapan untuk HR dan Organisasi yang Dinamis. Gramedia Pustaka Utama. Jakarta.

Irawati, Dwi dan Noor Mustakim, 2012. Pengaruh Komitmen Organisasional, Disiplin Kerja dan Motivasi Kerja Terhadap Prestasi Kerja Pegawai Balai Pelaksana Teknis Bina Marga Wilayah Magelang. Jurnal Manajemen. Universitas Muhammadiyah Magelang. Jawa Tengah. Vol. 22 No. 1 April 2012. Hal 2-7. 
Mangkunegara, Anwar Prabu, 2015. Sumber Daya Manusia Perusahaan. Cetak ke12. Remaja Rosdakarya. Bandung.

Mohklas, 2015. Pengaruh Kompetensi dan Motivasi Terhadap Kinerja Pegawai dengan Komunikasi sebagai Variabel Moderating (Studi pada Kecamatan Gayamsari Kota Semarang). Jurnal Penelitian Ekonomi. STIE Pelita Nusantara Semarang. Jawa Timur. Vol. 2 No. 1. Hal 99-118.

Muryanto, Eko, 2011. Pengaruh Kompetensi Terhadap Kinerja dengan Motivasi Kerja Sebagai Variabel Moderating (Studi pada Kantor Pengawasan dan Pelayanan Bea dan Cukai Tipe Madya Se-Jawa Tengah dan Daerah Istimewa Yogyakarta). Jurnal Ekonomi. Universitas Sebelas Maret. Surakarta. Vol. 1. No. 3. Tahun 2011. Hal 86-90

Pratama, 2012. Pengaruh Kompetensi dan Motivasi Terhadap Kinerja Karyawan $P T$. Indo Stationery Ritel Utama Cabang Samarinda. Jurnal Ekonomi. Universitas Mulawarman. Vol. 3. No. 1. Hal 1-23.

Rahayu, Julietta Putri Pangestika, 2017. Analisis Pengaruh Kompetensi dan Motivasi Terhadap Kinerja Karyawan (Studi Kasus pada Supervisor dan Staff di Ros-In Hotel Yogyakarta). Jurnal Penelitian Ekonomi. Universitas Sanata Dharma. Yogyakarta. Vol. 3 No. 1. Hal 90-93.

Rosidah, 2004. Pengaruh Kompetensi Sumber Daya Manusia Terhadap Kinerja PT. Cheil Jedang Indonesia Di Jombang Jawa Timur. Jurnal Manajemen. Universitas Airlangga, Surabaya. KKB KK-2 TPS.27/04 Ros p. Hal 12-23.

Satori, Djaman, 2007. Profesi Keguruan. Universitas Terbuka. Jakarta.

Setiawan, Heru, 2017. Pengaruh Kompetensi dan Motivasi Kerja terhadap Kinerja Pegawai di Badan Pengembangan Sumber Daya Manusia (BPSDM) Provinsi Jawa Barat. Jurnal Ekonomi. Fakultas Ekonomi-Universitas
Pasundan. Bandung. Vol. 6 No.5. Hal 120-130.

Siagian, P Sondang, 2003. Teori Motivasi dan Aplikasinya. Edisi 3. PT. Rineka Cipta. Jakarta.

Simamora, Henry, 2004. Manajemen Sumber Daya Manusia. STIE YKPN. Yogyakarta.

Spencer, M. Lyle dan M.Signe Spencer, 2007. Competence at Work:Models for Superrior. John Wiley dan Son. Canada.

Sugiyono, 2010. Metode Penelitian Kuantitatif, Kualitatif dan $R \& D$. Alfabeta. Bandung.

Sutedjo, Adji Sigit, 2018. Pengaruh Kompetensi dan Motivasi Kerja terhadap Kinerja Karyawan di PT. Inti Kebun Sejahtera. Jurnal Bisnis Manajemen. Universitas Mercu Buana, Jakarta. Vol. 5 No. 2 Februari 2018. Hal 120-129.

Umar, Husein, 2008. Metode Penelitian Untuk Skripsi dan Tesis Bisnis. PT. Raja Grafindo Persada. Jakarta.

Uno, Hamzah, 2009. Teori Motivasi dan Pengukurannya (Analisis di Bidang Pendidikan). Bumi Aksara. Jakarta.

Warningsih, Marselina, 2010. Pengaruh Kompetensi dan Motivasi Terhadap Kinerja Pegawai Sekertariat Wakil Presiden Republik Indonesia. Jurnal Ekonomi. Program Pascasarjana. Universitas Terbuka. Jakarta. Vol. 2. No. 2. Hal 2-14.

Wibowo, 2007. Manajemen Kinerja. PT. Raja Grafindi Persada. Jakarta.

Yuliana, 2017. Pengaruh Kompetensi dan Motivasi Kerja terhadap Kinerja Karyawan Perusahaan pada PT. Haluan Star Logistic. Jurnal Ilmiah Manajemen dan Bisnis. Fakultas Ekonomi-Universitas Kristen Krida Wacan. Vol. 17 No.2. Hal 135-150. 